\title{
Correction to: Conditional ablation of p130Cas/BCAR1 adaptor protein impairs epidermal homeostasis by altering cell adhesion and differentiation
}

Maria del Pilar Camacho Leal ${ }^{\dagger}$, Andrea Costamagna ${ }^{\dagger}$, Beatrice Tassone, Stefania Saoncella, Matilde Simoni, Dora Natalini, Aurora Dadone, Marianna Sciortino, Emilia Turco, Paola Defilippi, Enzo Calautti ${ }^{\ddagger}$ and Sara Cabodi ${ }^{*}$

\section{Correction}

Following publication of the original article [1], the authors reported an error in the name of the 11th author. The author's name was incorrectly published as "Vincenzo Calautti", instead of "Enzo Calautti".

The publishers apologise for this error. The original article [1] has been updated.

Received: 6 November 2018 Accepted: 7 November 2018

Published online: 26 November 2018

\section{Reference}

1. Leal C, et al. Conditional ablation of p130Cas/BCAR1 adaptor protein impairs

epidermal homeostasis by altering cell adhesion and differentiation. Cell

Commun Signal. 2018;16:73. https://doi.org/10.1186/s12964-018-0289-z.

* Correspondence: sara.cabodi@unito.it

${ }^{+}$Maria del Pilar Camacho Leal and Andrea Costamagna contributed equally

to this article.

${ }^{\ddagger}$ Enzo Calautti and Sara Cabodi contributed equally to this article.

Department of Biotechnology and Health Science, Molecular Biotechnology

Center, Università di Torino, Via Nizza, 52 Torino, Italy

(c) The Author(s). 2018 Open Access This article is distributed under the terms of the Creative Commons Attribution 4.0 International License (http://creativecommons.org/licenses/by/4.0/), which permits unrestricted use, distribution, and 